\title{
第17回日本看護科学学会学術集会シンポジウム II
}

\section{看護実践の構造と言語 Structure and Language of Nursing Practice}

\author{
座長 中 山洋 子(福島県立医科大学看護学部) \\ 安 藤 幸 子(神戸市看護大学) \\ シンポジスト 池川清 子(宮城大学看護学部) \\ 佐 藤 重 美 (長野県看護大学) \\ 高田早苗 (北海道医療大学)
}

\section{看護実践の構造と言語}

中山洋子・安藤幸子

看護が実践的行為であることは誰もが認めて いる. とりわけ，看護の理論を構築することよ りも実践することを重視してきたわが国におい ては, “看護行為”そのものが表現の一つであ り，“言語”による表現よりも確かなものとして 信頼を置いてきた歴史がある，それゆえ，看護 の担い手たちによって臨床のレベルでなされて きた研究の多くは, 看護現象や患者ケアの実際 を記述することによってケアの質を高めること に力が注がれ, 看護実践の構造やその特徵を明 らかにする方向には向かわなかった。 わずかに 「看護における判断と行為化」や「看護の実践的 行為(介入)の分類」などの研究を通して, 看護 実践の構造化や看護行為の言語化が試みられた に過ぎない.

一方，言語は，その社会の文化を表すものと されている。看護における言語の問題は，これ までに臨床における看護用語，すなわち，看護 記録に使われている用語の検討として取り組ま れてきた。 最近では，看護診断 (Nursing Diagnosis) や看護介入 (Nursing Intervention)の 分類に際しての用語が検討されている.これら は看護が独自性をもつ科学的な専門分野であろ うとする動きの中で，文化を越えた世界共通の 言語としての看護の専門用語を確立し, 体系化 しようとする努力とみなすことができる。こう した現状を踏まえながら，本シンポジウムでは，
以下の $3 つ の$ 論点からの問題提起をおこなつた.

第 1 は，「看護実践の構造とはどのようなもの なのか」という問題である。“実践知” “Knowing-how”といつた側面からも論じられてきて いる看護実践は，どのような特徵をもつものな のか. 行為としての看護実践は, 言語化するこ とが可能なのか. 看護実践は, 言語化すること によってその構造を明らかにすることができる ものなのか.

第 2 は，看護実践と言語の問題である。看護 は独自の “言葉(ことば)”をもてば，看護現象 を的確に表し，専門性を高めることができるの か、また看護実践 (看護現象, 看護介入) を言語 化し，それを分類することによって，看護の構 造を明らかにしたり，体系化することができる のか.

第3は，言語がその社会の文化を表すという 前提に立つたとき，セルフケアなど患者主体の 医療がめざされる中にあって，「看護独自の専門 用語をつくり，その体系化を目指すことはどの ような意味をもつのか」という問題である. 看 護実践はあくまでもその受け手である患者 (Client) との相互作用の中で成り立つものであ る、看護実践における言語は，誰のためのもの なのか.

本シンポジウムのシンポジストは，提起され た問題を受けて立ちながら，それぞれの立場か ら看護実践の構造と言語の問題に迫つた。 
看護実践における言葉への問い

$$
\text { 池川 清子 }
$$

はじめに

看護実践がどのように組み立てられているの かを知ろうとするとき，言葉はその組み立ての 表現方法として，そのすがたを我々の前に現す のである. 言うまでもなく, 看護実践は言語(対 話)によって構造化されている，つまり看護実践 の目的や哲学をどのような言語で構想し，その 実践過程をどのような言語で遂行し，どのよう な言語で意味づけ，反省するのか。 こういつた 一連の営みが，看護実践に他ならないのである。

したがって，看護実践をどのような言語で組 み立てようかという問題は, 看護学が実践学で あることの自明性との戦いであり, 看護学の本 質にかかわる課題を含むものと考えられる.

\section{1. 看護実践の主題化}

21 世紀を人々はケアの時代と呼ぶ。ようやく 我が国において，ケアもしくは看護実践が大き く主題化されるようになったと言えそうである. 実践(プラクシス)は，もともとは，アリストテ レスのテオリア(観想, 理論)，ポイエシス(制 作)，プラクシス (実践)の三分類に由来するもの で，そこでは実践に対する理論的認識の優位が 主張されていた。実践に対して理論的認識を優 位とする立場が, 存在しているものはく物とし て存在しているか＞又は＼cjkstart意識として存在して いるか>のいずれかという二元論を根拠とした 自然科学の目覚ましい発達を生夕出したことは 周知の事実である。このような学問の流れは, 主知主義 (実践よりも理論の優位を説き, 理論の 応用が実践であるという考え方) という形をもつ てこれまでの看護学にも大きな影響力を持って きたこともまた事実である.

このことは一見すると, 看護の理論化に勢い をつけ科学理論としての看護学の模索に近道で あるかのような錯覚を覚えさせる.しかし，少 し注意深く見てみると主知主義とは，とりもな おさず実践知を含む看護学が，自然科学的方法 に依拠する医学をはじめとする諸科学から立ち 後れてきた歴史そのものを肯定することに他な
らないことに気づかされるはずである. そこで は常に実践に対する理論的認識の優位が主張さ れてきた. 看護実践を主題化していくというこ とは，このような理論と実践との価值の上下関 係を逆転するとともに, むしろ実践の優位のも とに理論と実践との統合を目差すことであろう. すなわち, 看護学のパラダイムが医学的パラダ イムから実践的パラダイムへと転換させること を意味している，それは，医療や看護をとりま く現代社会のさまざまな構造的な変化に注目す るということにとどまらず，もつと基本にある 根本のもの, 我々の考え方や感じ方の前提とな つている枠組あるいは地平そのものの変化を意 味しているからである.

\section{2. 看護実践における言語化の意味}

看護のパラダイムは, 当然のことながら, 言 葉に対する根本的な問い直しをもたらすのであ る.今回のシンポジウムのテーマ「看護実践の 構造と言語」を私なりに解釈すると，まず看護 実践における言語化の意味を問い，そこから実 践の構造に迫ろうとするものとして捉えた.

すなわち, 学問用語としての言語化の意味す るところは, 現象としての看護をどのようなも のとして概念化し，どのようなものとして現実 化していくかという行為を意味しているのであ る. 言い換えると看護学の methodology学問 的方法論そのものであるといえる. 近年の言語 学の成果は, 言葉がかつて考えられて来たよう に，すでに出来上がった概念や思考をただ言い 表すものではなく, むしろ概念の母胎であり思 考の地平そのものであることを我々に教えてい る. 言い換えると, 言葉は看護をするための単 なる手段ではなく，もっと看護実践にとつて実 質的ななにか，我々がそれを生きることによつ てのみ看護自体が成立する，したがって，それ なしには看護者の成長も相手の変容も起こり得 ないような，人間の根本的なあり方のすべてを 含んでいるようなものとして現前しているので ある。

看護学を概存の諸科学, つまり医学や社会学, 心理学から区別して一個のディシプリンたらし めようとする努力, 即ち看護学の実践的パラダ 
イム創出への挑戦は，まず，看護実践をとりま く現実や世界を読み解くための基本的用語を洗 い直すことから始めなければならないであろう.

話題を「人間」との関係に限ってみても, 我々看護者が「患者というトータルな人に焦点 を当てる」というときの患者とはどのような人 間を想定したらよいのだろうか。また「看護診 断」を看護実践の方法として導入するときの, 診断する側, される側の人間は, どのように概 念化され，イメージ化されているのだろうか. パラダイム転換とは，基本用語を中心とした世 界の言語的組み替えと言える所以である.

\section{3. 看護実践の基本的構造}

1 ）構成主義とゲシタルトの問題

看護実践の構造とは，とりもなおさず看護者 と看護の援助を要する人との間で成立する体験 の場を意味するものと考えられる。看護者は相 手の状況を知覚することによって行為し, 行為 することによって知覚する.この知覚と行為の 相補性が看護体験の基本構造である。ここでの 体験の場とは, 看護行為に内包されている意図 や目的とその実現の場にほかならない. 我々看 護者の知覚意識が目で見, 耳で聴く, 手で触れ るといつた看護者自身の身体に根差している限 り，世界から隔絶した意識では有り得ない。物 は，意識は持ち得ないからである.

ここで知覚をめぐる二つの立場について, 再 認識したいと思う。いわゆる要素構造主義とゲ シタルトの問題である。これら二つの立場を身 近な例で見てみると, 看護者が一人の人間をど う捉えるかという点において，その差異は明確 である。一方は, 人間を身体的, 心理的, 社会 的，という三つの側面から見ようとする立場， つまり, 要素構成主義的見方であり, 他方は, 人間をまるごとトータルに把握したいという時, 即ち, ゲシタルト的見方である.

これまでの要素構成主義的な考え方によれば, 知覚とは, 恒常的で要素的な刺激 (センス・デー 夕)に連想や推理などの高次の心理的過程が外部 から加わることによって生じる，とされていた。 それに反してゲシタルトとは, 部分の加算的総 和に還元されない全体的構造のことである。例
えば, メロディーのように要素に分解したので は霧散してしまうそれ自体が，一つの全体であ るような性質のことをいうのである.

以上二つの立場, 要素構成主義とゲシタルト の立場を考えること(思考) と話すこと(言葉) と の相互作用から見てみると, 前者は言葉と言う ものをそれによって表現される思考とは別な外 在的記号として見がちであった，思考は人間の 内面に伏在するものとして，また言葉は，外面 的，物体的現象として見られるわけである.こ の場合，言葉の持つ意味すなわち思想は，言葉 を必要としない. なぜなら，思考はそれが語に 表現される前にすでに存在しているからである.

他方, ゲシタルトすなわち全体論の立場の主 張は, 我々の思考はまず内的に完成され, 次に その表現の為の語が見つかるのを待っていると 言ったものではない，思考は，己自信の完成と して言葉を求めるのである. 自分のぼんやりと した考えが，書くことによって，書き進むにつ れて，明らかになってくることを我々は常に経 験している.

看護実践の場とは, 看護者と援助を要する人 がシンボルや言葉の交換を通して，ともどもに 一定の意味を形成していく創造的な出会いの場 であると言える。このような対面的状況におい ては, ことばは相互性という固有の性格をもつ ている，対話におけることば，話し相手の不断 の主観的意図と感覚的に同時化される. 双方は, 話すことばを実際には同時に聞いているのであ り，これが，看護者と相手の主観性への不断の 同時化された相互的な，接近を可能にするので ある.つまり，このことは，言葉が相互主観的 世界とその経験において成立するものであるこ とを物語るものである。

2) 言葉の相互主観的性質

看護実践における言葉の相互主観的性格は, 看護者の意図や行為が相手との相互行為の中で はじめて成立することも意味している，その 時々の, 看護行為の実現の仕方は, どのような 相手と出会うかによって行為の仕方は，不断に 変化することになる．また，その逆も真である ことはいうまでもない. 看護行為の過程では, あらかじめ意図されていたことがすべて実現す 
るわけではないし，時には，実現していたこと が意図されていたこととは限らないのである. 意図による行為の説明や理解は, 行為が終わつ た後からなされる合理化の試みである場合も少 なくない.

いうまでもなく，我々は日常生活において常 に「合理化」を行っているし，むしろそのこと を通して，自分が何をしようとしているのかを 理解することが出来ているといえるであろう. しかし，看護行為が相手との状況の中で成立す るためには，合理化は行為者の自己反省を前提 条件とするのである，この合理化と自己反省は 看護者の意図と行為との間で生じ続ける「逆転」 へと開かれている必要がある，というのは，こ の経験への開放性が閉じられると，自己反省は 常に一定の方向へとあらかじめ決定されてしま うことになるからである.

看護実践における言葉への問いは，当然のこ とながら従来からの我々の他者経験，他者理解 への問いを生じさせる.つまり，実践を心と物， 主観と客観の分離対立の枠組で捉えようとする と，経験は一方では内的知覚の対象である自己 の体験（ひとりよがりの思い込み）であり，他方 では外的知覚の対象である物的条件 (物化) でし かない. したがって，この枠組での他者理解は， どうしても外的知覚に媒介された二次的なもの にならざるを得ない。この場合，類推や感情移 入などが用意されているのであるが，いずれに しても他者の意識内容に到達することは困難で あり，真の他者理解にはほど遠いものと言わざ るを得ない. 相手不在のきめつけが横行する結 果をまねくことは必定であろう。

看護実践の現実が，看護者が他者とともに共 有する相互主観的な世界としてあらわされると き，そこでの他者理解の問題は，言葉の問題が そうであるように，どうしても二元論の枠組自 身を問い直す必要に迫られるのである.

おわりに

看護実践における言語化の問題は，看護実践 の本質の解明に関わる課題であって，ある現象 にラベリングしたり，ネーミングしたりするこ と，すなわち，実践そのものを客在するものと
して，それをどう呼ぼうかというようなことと は，次元の違う問題である.

看護における言語化の方向が医学と同じよう な共通言語化をはかるということであれば，実 践知としての看護のありかたは学問的に無視さ れるということであり，看護学の独自性は望む ベくもないであろう.

看護における言語化とは，言葉を通して他の 学問とのコミュニケーションを可能にするもの でなくてはならないし，そのことによって初め て専門性の確立も可能になるのではないかと考 える。

\section{参考文献}

1）早坂泰次郎：人間世界の心理学一日常経験 の現象学的人間学をめざして一, 川島書店, 1978.

2) 池川清子 : 看護における哲学的課題一看護 技術論への試み一(山崎智子監修，基礎看 護学 I 収録)，金芳堂，1996.

3 ）池川清子，看護一生きられる世界の実践知, ゆみる出版, 1991.

4) Jean Piaget, 芳賀純訳 : 発生的心理学一 子供の発達の条件 (第2 版), 誠信書房, 1972.

5 ）河上正秀: 行為之意味一技術時代の人間像 一, 未知谷, 1991.

6 ) Merleau-Ponty，竹内芳郎，小木貞孝訳 : 知覚の現象学 I (第9版), みすず書房, 1945 .

7 ) 村田純一：知覚と生活世界一知の現象学的 理論一，東京大学出版会，1995.

8 ）中村雄二郎：問題群一哲学の贈りもの一, 岩波新書, 1988.

9 ）中村雄二郎：術語集一気になることば一, 岩波新書, 1991.

10）中村雄二郎：臨床の知とは何か, 岩波新書, 1992. 


\section{看護実践の共通言語化と看護学の発展}

佐 藤 重 美

\section{はじめに}

看護現象を明確に表現し，共通言語として確 立させようとする動きが，世界各地で急速にそ して着実に進行している。北米では看護診断 Nursing Diagnoses, 看護介入Nursing Interventions, 看護結果Nursing Outcomes用語 の開発・分類作業がそれぞれ進行中で，これら に対して多くの国のナースが関心を寄せている. 一方で, 国際看護婦協会 (ICN) は世界という視 野を最初から念頭においた, 看護診断・介入 ・ 結果を全て含む共通言語の分類体系化に着手し ている，なぜ今，看護実践を表現する言葉が必 要とされるのか。 それも国毎ではなく，世界中 のナースが共有できるような看護実践の共通言 語が必要とされるのであろうか。本稿では看護 実践を言葉で表現することの意義，そして看護 実践を表わす言葉を世界中のナースが共有する ことの意義を看護学の発展という視点を交えて 考察する.

\section{1. 看護実践の共通言語化作業}

まず，看護実践を表現する言語が必要とされ た背景を振り返り, 看護診断・看護介入・看護 結果のそれぞれの分類作業と, 看護実践国際分 類における具体的な取り組みを紹介する.

\section{1 ）看護診断用語の分類}

1970年代の米国では，病院情報管理へのコ ンピューター導入が進む一方で, 簡潔で系統化 された看護用語の不足が明白になっていた。ま た病院経営の合理化が始まり, 多職種が医療于 一ムを構成するようにもなり，病院経営者に対 して看護の専門性を明確な言葉で説明する必要 が生じていた。そこで，看護問題を明確に表現 する，引いては看護の専門的守備範囲を明らか にする言語を検討すべく，1973年にミズリー 州・セントルイス大学で開催されたのが, 全米 看護診断分類会議であった ${ }^{11}$. 看護実践の共通 言語化の出発点は 25 年前のこの会議であるとみ なすことができよう。全米看護診断分類会議は 隔年で開催され，1985年には北米看護診断協
会North American Nursing Diagnosis Association (NANDA)と名称を改めている. NANDAも隔年で学術会議を開催し，看護診断 用語の開発・分類作業を継続しており，これま でに128の看護診断カテゴリーを提案している2). 看護診断用語の体系化作業が完成するまでには 何十年，何百年もかかることを念頭に置き取り 組みが始まったという点には着目すべきであろ う.

\section{2）看護介入用語分類}

看護実践を表現するためには看護診断用語の みでは不十分であるとして, 看護介入用語の分 類Nursing Interventions Classificatio (NIC) も始まった。1987年にJ.McCloskeyとG. Bulechekを代表に，アイオワ大学に研究者50 名からなる大規模な研究チームが組織された。 米国内では医療用データベース作りが優先され たこともあり，国立看護研究所National Institute of Nursing Researchは1990年から7年 間にわたり，NIC研究チームに対して多額の研 究資金援助を行ってきた.この結果，組織的な 研究による膨大なデー夕処理が可能となり, 現 在までに 433 の看護介入用語がまとめられてい $る^{3)}$.

\section{3 ) 看護結果用語分類}

米国内では 1990 年代に入り，医療の質に対 する国民の関心が高まるようになった。医療の 質を測定するためには，死亡率，感染率，再入 院の割合，入院期間といつた指標で医療・治療 の成果や結果を評価することが多い。看護婦は 医療チームの一員として患者ケアに関りこれら の指標に少なからず影響を与えている。しかし， 具体的にはどの看護介入がこれらの結果に結び つくかの判定は難しく, 看護の貢献度が不明と いう問題があった．看護の行う独自の介入の有 効性を，より直接的に評価するために着目され たのが，看護結果用語である，看護結果用語分 類 Nursing Outcomes Classification (NOC) を行っているのはM. JohnsonとM. Massを代 表とする 17 人の研究者から構成される研究チ一 ムで, 1991 年にアイオア大学で結成された. 国 立看護研究所はこの研究プロジェクトに対して も1993年から 4 年間の研究資金を援助してき 
た。現在までに190の看護結果用語がまとめら れている4).

\section{4）看護実践国際分類}

1991年に国際看護婦協会 (ICN)が行つた調査 からは，北米以外の多くの国でも，看護実践言 語の開発や分類が急速に進んでいることが判明 した ${ }^{5)}$ そこで，世界中の看護診断・介入・結 果用語を整理し，各国の看護実践言語を統合す るような枠組み作りが必要になってきた。これ が看護実践国際分類International Classification for Nursing Practice (ICNP)である. ICNは世界中で通用するものということを最初 から目標として取り組んでいる. しかし実際は, ヨーロッパの会員を主動力として作業が進んで きたようである。ヨーロッパでは欧州連合が， 看護記録の共通枠組みコンピューター化に取り 組んでいる，そして，テレナース Telenurse ${ }^{6)}$ と呼ばれる，コンピューター化された患者記録 情報の伝達・交換にICNPの活用をめざしても いる. そのため, ヨーロッパ各国のICNPに対す る期待は高く, 研究開発にも積極的に協力して いる.

現在のICNPは $\alpha$ バージョンと呼ばれ, 日本 でも翻訳が出ている7). アルファバージョンは 1998年末までの期限付の有効である。この間 に，ヨーロッパのテレナース・プロジェクトが フィールド・テストをしたり，世界各国からの フィードバックが期待されている。 これらを踏 まえて, 1999 年には $\beta$ バージョンと呼ばれる新 しい分類が発表される予定である.

\section{2. 日本文化と共通言語の相性}

前述した「看護実践の共通言語」はどれも, 本来は英語で表現されたものであり，我々が使 うためには日本語への翻訳が必要となる。 そこ で生じる疑問は，このような外国製の共通言語 は日本でも「共通」だといえるのか? 言い替え ると, 外国生まれの言葉は翻訳されたとしても, 文化の異なる日本で通じるのであろうか? 筆者 ${ }^{8)}$ はNANDA看護診断概念の日本における妥当性 検討を通して，これを明らかにしようとしてい る.

\section{1）概念構造を示す理論}

検討を進めるに当たり, 看護実践の共通言語, 看護実践を表現する個々の言葉を「概念」とし て捉えることが必要になる，そうすると先の疑 問は，概念というものが文化によって異なるの か? ?置き換えることができる. 概念の構造に 関しては二つの理論に着目している. 概念はそ れぞれの文化により異なるのだというShwanenflugelらの説 ${ }^{9)}$ と概念は二段構造であるとい うMichalskiの説 ${ }^{10)}$ である.

Shwanenflugelらは，(1) 言語，（2）熟知／ 親密性，（3）知識基盤，（4）文化的典型の4要素 が関係していることにより，概念は文化により 異なるのだと説明している.これら4要素はそ れぞれ独立した要因ではなく，実際は複雑に関 連している。特に, 言語, 熟知 $/$ 親密性, 知識 基盤があって，第4の文化的典型と呼ばれるよ うな概念の典型的なものが, その文化内で形成 されると考えられる.

ジョージメイソン大学の人工知能研究者 Michalskiは, Two-tired concept representationという表現を使い, 概念が二段構造を持 つことを説明している，概念には概念の根本的 な特徵を示す安定した部分と, 状況により変化 する部分があることが示されている.

\section{2 ) 看護診断概念モデルの構築}

上記二つの理論を統合して検討してみること により，新たな視点を得ることができる. Michalski ${ }^{10)}$ のいうように概念が二段構造であ るということは，つまり，世界的に共通する安 定した部分と, 文化毎に変化する部分があると 考えれば良いのではないか。つまり，Shwa-

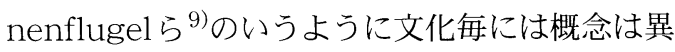
なるが，それは概念の一部分にすぎないとも考 えられるのである，そこで図1に示す，看護診 断という概念の構造を表わすモデルを構築した. モデルは看護診断概念の中心，概念の中核にど んな文化にも共通する概念の特徴 (診断基準)が あり，その周りに文化毎にみられる概念の特徵 (文化毎の診断基準)のあることを示している.

3) 外国性共通言語を使用する際の課題

前記のモデルが示すように，異なる文化間で も看護実践の共通理解，共通言語化は可能だと 


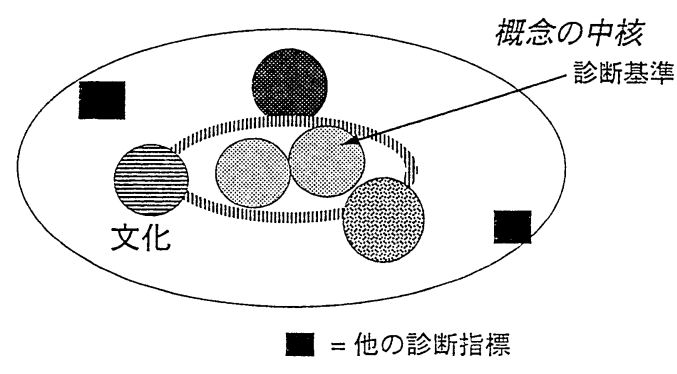

図1 看護診断概念の構造モデル

いえよう．ただし概念の妥当性検討により，文 化により異なる部分を明らかにする必要がある. また，看護診断では日常的でない不自然な言語 化が問題となっているが，英語を直訳したこと が原因と考えられるものが多い，外国語で表わ された共通言語を日本語訳する際には細心の注 意が必要である，外国語で表現された意味をま ず理解して，適切な日本語を探したり造ったり という方法もこれからは取り入れて行くべきで はないだろうか. さらに, 可能な限り共通言語 の開発段階から日本人が積極的に参加協力すれ ば，日本文化を反映させた共通言語作りが可能 になるとも思われる。

\section{3. 共通言語化と理論構築}

学問としての看護学の目標は知識の発展, つ まりより実践に役立つ理論の構築だといえる. 看護実践の共通言語の個々を「概念」として捉 えたと前述した。概念は物事の本質的な特性を 捕えた思考であり，人間の思考を作り上げてい る要素でもある，概念が言語として表現される ことで, 自分以外の他とのコミュニケーション が可能になる。看護実践の共通言語化は概念の 明確化であると考えられる.

看護を学問として発展させるためには理論の 開発が必要だが，理論には以下のような4つの 発達段階があることをDickoff と James ${ }^{11}{ }^{1}$ は説 明している。

I . Factor-isolating theories

II. Factor-relating theories

III. Situation-relating theories

IV. Situation-producing theories

第一段階, Factor-isolating theories とは概 念の明確化を意味する．個々の概念が明確にな
ると, 概念と概念の関係を示す, 次の段階の理 論, Factor-relating theoriesの構築が可能に なる。言い替えれば，概念の明確化なしには， 高度の理論は発達しえないことになる。したが つて，集団の知識体系，つまり学問を構成する 一つ一つの要素として概念は重要だといえる. まだ知識の積み重ねが十分でない看護学にとつ て, 最も必要な作業が, 理論発達の第一段階, 看護領域概念の明確化といえる。看護実践の共 通言語化をめざす看護診断，看護介入，看護結 果の開発・分類作業は，看護領域における概念 の明確化である。これらの分類作業が進めば, 看護診断を中心に介入や結果の関連性を明らか にすることが可能で, 引いては高度な理論の構 築にもつながることになる.

\section{4. 国際協力と看護学の発展}

国際協力の視点からしても, 看護実践の共通 言語化は意義があり，その必要性が高いといえ よう。看護の学問としての目標は知識の発展, 実践に役立つ理論の構築である。この目標達成 のために必要なことは, 看護学という知識体系 全体としての知識の積み重ねであり，継続的な 理論の再検討である. 看護実践が共通言語化さ れると, 国内外を通しての情報交換が可能とな る. つまり国内外を通しての研究協力が可能に かつ容易となり, 同じ現象に興味を持つ世界中 の看護研究者の間で情報交換が効果的に行える ようになる。これは, 結果的には学問全体とし ての資源や労力の無駄遣いをなくし，迅速な看 護学の知識発展につながると考えられる.

コンピューター技術というハードウェアーの 進歩と普及に，看護実践の共通言語というソフ トウェアーを活用することで，学際的な情報交 換の可能性は無限大に広がると予想される．例 えば既に共通言語化の恩恵を我々が受けている ものがある. CINAHLやMEDLINEのようにオ ンライン化された文献検索システムは，今日は いつでもどこでも利用可能である。 そして，関 心ある分野の世界的な知識の積み重ねの検索が, 数分のうちに完了できるまでになっている.

より実際的なレベルでの国際協力を考えた時 にも，看護実践の共通言語化は必要である，経 
済社会の変化に伴い，閉鎖的であった日本にも 外国人が増え, 看護の対象も国際的になってき ている，様々な文化背景を持った対象の二ード に合った看護を展開するためには，世界的視野 で看護現象や看護実践を理解する時が来ている といえよう。

おわりに

"If we cannot name it, we cannot control it, finance it, teach it, research it or put it into public policy.”「名前を付けられなけれ ば，コントロールすることも，資金を融通する ことも，教えることも，研究することも，政策 に反映させることもできない.」これはICNPの コンサルタントとして活動しているNorma Lang $^{12)}$ の言葉で，看護実践の共通言語化の必 要性と意義をもつとも的確に表現している.

看護学にそして看護実践に共通言語が必要か 否かは，もはや国際的な論点ではないという現 状を日本の看護婦, 看護教育者そして看護研究 者は認識すべきである，現在の論点はどのよう に共通言語を発展させたらよいかに移行してい る.コンピューター技術が進歩し，情報化がめ まぐるしく進む国際社会から取り残されないた めにも，世界規模での看護実践の共通言語化に， 我々も真剣に取り組むべき時ではないかと考え る.

\section{引用文献}

1) K.M. Gebbie, M.A. Lavin編 : Classification of nursing diagnoses: proceedings of the first national conference, The C.V. Mosby Company, 1975.

2 ) NANDA: Nursing Diagnoses: Definitions \& classification, 1997-1998, NANDA, 1996.

3 ) J.C. McCloskey, G.M. Bulechek編 : Nursing interventions classification, Mosby, 1996

4) M. Johnson, M. Maas編 : Nursing outcomes classification, Mosby, 1997.

5 ) Wake, et al: Toward an international classification for nursing practice: A litera- ture review \& survey, International Nursing Review, 40 (3), 77-80, 1993.

6 ) ICNP in Europe: Telenurse, International Nursing Review, 43 (6), 188-189, 1996.

7 ）特集，看護の共通言語を構築する，看護実 践国際分類 (ICNP) /アルファバージョン, インターナショナルナーシングレビュー, 20 (3), 1997.

8 ) Sato, S.: Diagnostic Concept Development: Content Validation of North American Nursing Diagnoses in Japan, Unpublished doctoral dissertation, Boston College, 1996.

9) P.J. Schwanenflugel編 : The psychology of word meanings, 71-90, Lawrence Erlabaum Associates, 1991.

10) I.V. Mechelen et al. 編 : Categories and concepts, 145-172, Academic Press, 1993.

11) Dickoff, J., James, P., \& Wiedenbach: Theory in a practice discipline part I : Practice oriented theory, Nursing Research, 17 (5), 415-435, 1968.

12) Clark, J., \& Lang, N.: Nursing's next advance: An international classification for nursing practice, International Nursing Review, 39 (4), 109-111, 128, 1992.

\section{看護実践に内在する特徵と言語化の方向}

高田早苗

看護実践を言語化することの難しさは実に 様々な場面で多くの看護婦に体験されてきた. 患者の人となりを物語るエピソード, 心躍る展 開をいざ記述しようとする時，そのリアリティ， 豊かな意味合いを表す言葉に窮し，もどかしさ を感じる.おそらくこの困難は，実践そのもの の性質あるいは特徵に関係がある。言語化の問 題は，また看護実践の構造を探る，あるいは構 造化をどのように図るかという問題にも深く関 わる. とる立場で見えてくるものが異なり, 自 ずから用いる言語も違ってくるからである. 看 護実践の構造を探る視点, 実践の特徵を検討し, 
そこから構造化と言語の問題に迫りたい.

\section{1. 看護実践の構造を探る視点, 論点}

実践の構造化を考えるとき, 幾通りかのアプ ローチがあることに気づく，先ず，個別ケアの 成り立ちをどう捉えるかという視点がある。こ のなかには，主に看護者の判断一行為過程を重 視する立場がある．アセスメント一診断一介入 一評価といつた看護過程が代表的なものである. 看護婦の思考過程を中心においているところか ら，必然的に患者(の現実) は客体として扱われ ることになる。

次に，対象者である患者との相互作用を中心 とする立場がある。看護婦と患者の相互作用に よって看護の実践そのものが生まれ，規定され るという考えである. 患者のその時々の反応に よって惹起される看護婦の思考や感情, 看護婦 の行為, そしてそれらの相互作用が組み込まれ ている.こちらは言うまでもなく, 相互作用／ 人間関係理論に例をとることができよう。看護 過程が認識・思考あるいは客観性を重視するの に対して, 感情・情緒的な側面を強調すると見 ることができる. 加えて, 患者その人にとって の意味を重視する立場でもある.

実践が行われる状況を視野に入れたマクロの 視点から実践の構造を捉えることも可能であり, かつ重要と考える. 個別ケアの成り立ちを明ら かにすることだけでは実践を捉えきれない。も ちろん，個別ケアそのものにも文脈はあり，患 者の歴史や文脈がないがしろにされているわけ ではない，ここで言うマクロな視点とは, 患者 と看護者をとりまくより大きな状況を指してい る. 看護実践はさまざまな社会文化的・経済的 状況のなかで行われる. 実践の内容やその質は, 看護がおかれている状況との関連を抜きに考え ることはできないし，状況による規定を免れる ことはできない，先ず，施設や病棟の特性，保 健医療チームの文化とでも言うべき状況がある. 身近で強力な影響力をもつ医師集団, 医療実践 があり，どんな考え方の医師たちとチームを組 むかによって，実践で何が重視され優先される かは異なってくる．管理者の運営方針，組織機 構のあり方も大きく関わるのは周知の通りであ
る. 看護婦の裁量できる範囲はどのくらいある のか, 雾囲気は専門職としての自律を促すよう なものかむしろ阻むか．患者に許容されている 選択の範囲はどうか, 規則は一律できっちりし ているかゆるやかで幅のあるものか.これらに よって看護婦と患者の間で交わされるやりとり はかなり違ったものとなるだろう.

さらにより大きな状況として, 社会の変化や 保健医療行政の変革がある。我が国で現在進行 しつつある人口の高齢化, 慢性病／障害の増加 に伴う施設内から地域・在宅へのシフトを考え るとよくわかることである。 今や地域や家庭で の生活という視野を欠いた実践では不十分であ る. 加えて入院期間の短縮化への動きは加速度 的であり,これらの変化が看護職の仕事の仕方 一実践に与える影響はかなり大きいと見なけれ ばならない.

残念なことに看護職はこれまで状況の影響を 受けることはあっても，状況を変えたり新たな 状況を生み出す機会はきわめて限られてきた。 しかし最近このような機会は増え, 看護職も積 極的に発言するようになってきている. 実践の 質を向上させる取り組みは, 内側だけに目を向 けるだけでは不十分だということに私たちも気 づき始めたのである.

\section{2. 看護実践 (構造)の特徵}

看護実践には明確な対象者があり，その対象 者の生活に関わる何らかの援助行為が看護の実 践であると言ってよいだろう。看護実践にはど んな特徵があるのだろうか.

1）個性的かつ多様であること

これは看護だけに特有なものというより，実 践に内在する特徵である. 実践の対語である理 論と対比してみると，理論は一般的普遍的であ る(あろうとする)のに対し，実践は具体的個性 的であるという特徵がある。例えば，一人一人 の看護者は, 個性的なケア・スタイルをもって いる，患者への接し方，声のトーン，身体を支 える手の位置や添え方から，ある状況下におけ る判断や解䣋の傾向まで，看護者の表し方は実 に様々である，興味深いことにこのように多様 でありながら，優れた看護実践家の動きは気持 
ちのよい緊張感や軽やかなリズムを感じさせ， 患者に心地よさや安らぎを, その場に秩序と調 和をもたらすという点では共通している。 また 優れた看護婦は対象者である患者の個性や状況 に合わせて微妙に変化させる．これらのことは 看護がひとつの表現でありアートであることを 如実に表していると言える。身体性や価值観, 看護センスが表れる個性的な実践は，創造性の 源であり, よい意味での多様性を生み出し, 実 践を豊かで魅力的なものにしている.

実践を表現することの困難さの多くはここに 由来している，つまり，看護がアートであるこ とを示すこれらの特徵故に, 記述や説明が難し いのではないだろうか. 美術にしろ音楽にしろ, 個人的な感動を他の人にことばで伝え，わかっ てもらうのには大きな限界がある，芸術作品ア 一トは感覚するもの, 味わい鑑賞するものであ り，そのすばらしさや感動は体験しないとわか らないものであるから.

\section{2 ) 時間的特徵}

看護婦の援助の成り立ちを研究した記述を見 ると, 看護婦の判断と援助行為はしばしば瞬時 に結びつく形で, 即時的になされていることが わかる，看護婦はある予測や計画をもって臨ん ではいても, その時の患者の反応や行動を捉え, 柔軟に微調整しながら援助するのが常である. 看護の実践では, 医学実践の場合のように診断 と介入の時間的あるいは方法論を明確に区切る (区切れる)ことは実際に少ない，優れた看護実 践であるほど, 援助の必要性 (あるいは問題, 診 断と言おうが)の判断と援助行為には距離が少な い.まさにWiedenbachの言う need for help の見極めが大切なのであり，それが患者との間 で明らかになること自体に援助が組み込まれて いると見ることもできる. このことは，看護を 診断一介入(治療) という枠組で見ようとするこ とへの反証のように思われる，つまり，看護診 断一介入という枠組みは観念的には可能だが, 看護実践の本質的特徵を必ずしも表してはいな い.

もう一つの時間的特徵は, 看護援助における 「時」とタイミングの重要性である. 経験のある 看護者には自明のことと思われるが, 患者にと
つて決定的な「時」がしばしばある.そのこと に無自覚な援助はもはや援助とならず，患者に は押しつけとしか映らない. 成功する看護援助 は必ずといってよいくらいに患者にとっての 「時」を掴んだものである．患者にとつての「時」 を捉える看護援助には，個人史的な見方が不可 欠なように思われる.これまでの患者の人生, そして今ここに在るその人, 優れた看護者は患 者とのちょつとしたやりとりから, 想像力を働 かせ思いをめぐらせる. 外口 (1988)はこのこと を「来し方行く末」と表現している. そしてこ の「時」を捉えることが可能なのは, 看護が短 時間の診察や週 1 回の面接という決まつた時間 内の関わりではなく, 必要によっては生活密着 型の 24 時間サービスであるという時間要素にも 関連している.

3）主体としての患者

最後に最も重要な特徵として, 看護実践にお ける真の意味での主役は患者であることがあげ られる。看護の実践は自己完結的な行為ではな く, 自ら選択し決定する患者の求めに応じる援 助行為である. 看護婦にとってではなく, 患者 にとっての「意味」を重視することは，多くの 理論家の強調を待つまでもなく, 看護の哲学的 基盤として共有されてきた。病気や入院という 体験に伴う意味は個人によって異なる，優れた 実践家は想像力を働かせてその意味に迫ろうと するし，患者と共に意味を探ろうとする．現に， 実践の結果は患者の側の要因によってかなりの ところ決定される．おそらく援助職に共通する ジレンマは, 援助者の側には問題の様相が見え ていても，時にはそのことが何の役にも立たな いことだ，看護婦は解説者や評論家ではない. 真の主体者である患者にとっての意味を問うこ となしに, 看護実践はあり得ないし, あったと しても倫理的観点から多くの問題が指摘されよ う.

このことがもつとも問われるのは, 科学的実 践装置としての看護過程, あるいは看護診断一 介入の枠組みではないかと思われる.

\section{3. 実践の構造と言語化の方向}

以上見てきた看護実践に内在する諸特徵から, 
実践の構造をどのように探るか，言語化の方向 をどう考えるかについて，いくつかの問題提起 をしたい.

\section{1）実践の知という観点から}

看護実践には，看護学の多様な知のパターン (Carper,1978) が組み込まれている。看護婦は 実践において，経験empirical知（あるいは科学 知）だけではなく，既に見てきたアートである美 学的知や個人的知そして倫理的知を用いている のである.これらの知のパターンのいずれが久 けたとしても，その実践は不確かで危ういもの となるだろう。 今のところ, これらの知のパタ ーンは別々に関心が向けられ発展してきている ように思われる。 しかし， ある局面ではある知 のパターンがもつぱら用いられるという性質の ものではなく, 統合された形で用いられること は確かである．これらの知のパターンが実践で 用いられる際にどのように統合されるのか, 看 護者としての形成過程とどう関わるのかなどは むしろ今後の課題であろう. 実践の構造を探る とき, 特定の知のパターンを焦点化しただけで は不十分であり，これらの知の結びつきという 観点が重要になると考える.

\section{2 ）患者の生活言語との共通性の模索}

看護実践の言語化は，専門家集団における共 通言語の獲得一学的体系化と切り離せない形で 議論されてきた. 確かに体系的な言語を発展さ せることは, 実践から出発した看護を, 専門職 実践の基盤となる学問として内外に示すために 不可欠であろう.「看護診断」への傾倒や情熱は その表れと見ることもできる.しかし，人々に とって身近な援助職として成り立ってきた看護 の歴史, 家庭や近隣における相互的なケアをそ の裾野とする実践を考えると，専門家集団内の 共通言語という考え方だけでいいのだろうかと いう疑問を抱かずにはおかない。論理や科学技 術の発展によって支えられてきた現在の社会で 認められる専門職を目指そうとするなら，人々 との距離は遠くなるかもしれない。これまでの 社会で優勢を占めてきた物差しで看護の実践を 測り，基準に合うように自分たちを実践を変え ていく危険性をはらんでいる。このことは看護 が専門職としての成立を目指すことに関わる一
種のジレンマである.このジレンマを克服する 道は，既存の枠組みそのものを問いなおし，そ れに代わるものを提出する試みに他ならない.

看護が患者や家族といつた人々の側に立つ援 助職として, 患者との親密さという特質を失う ことなく，その専門性を発展させ発揮していく には，共通言語の方向性は，専門家集団内の共 通言語ではなく，患者の生活言語との共通性を 模索すべきだと考える. 看護実践の目的からし て真の主役は患者であり, 実際に患者は看護者 の想像を越えた努力や工夫をしている。言うな れば患者も実践をしているのである，看護実践 が患者の努力や工夫といつた取り組み・セルフ ケアを支えるものであるなら，そこで用いられ る言語はむしろ患者との間でふつうにやりとり されることばと考える方が自然なのではないだ ろうか.

3 ）実践の豊かさを反映させることばを

最近見られる現象として動詞の名詞化がある. もつとも頻繁に用いられているのは，「ことばか け」であろうか. 行われる実践そのものにはも ちろん意味があり，そこに問題があるというこ とではない.しかし，このような動詞の名詞化 に違和感と危惧を感じるのは筆者だけであろう か.「ことばをかける」というときには，どんな タイミングで?どのように? どんなことばをか けるのか?といつたことが次々と浮かんでくる. つまり, 状況判断あるいは文脈を読むことがそ のことばには組み込まれている，それが「こと ばかけ」という名詞形になり，例えば看護計画 に「ことばかけを多くする」と記入されるとき, その言葉が本来持っていた生き生きとしたイメ 一ジは失われ，平板で機械的な印象を与える.

これでは豊かな実践というよりは貧相で官僚的 な実践のイメージである. 患者の状況を表すこ とばにも多くの問題が潜んでいる。「知識不足」 「受容できない」などといつたことばには，既に ある種の意味, 多くの場合ネガティブな意味が 付与されてしまっている. 討議では, 様々な二 ユアンスや見方が出されているにも関わらず, いざ文章化されるとそれらは雲散霧消してしま い，およそステレオタイプなことばの羅列にな ってしまう. 
恐ろしいのは，このようなことばが逆に概念 を規定してくる，そのようなことばを用い，伝 え合っているうちに実践がそのようなものにな ってしまいかねないことである.

看護実践の記述では, 力を失った既成のこと ば，決まり切った言い回しに頼らずに，自分の ことばで言い表す苦痛を伴う作業が必要なよう に思う。共通言語に向かうというより，むしろ 個々の看護者が個性的な表現を恐れずにしてい くことである．遠回りかもしれない，だが，こ の過程のなかで生き残ることばこそきっと実践 を言い表すことばに違いない.

\section{引用参考文献}

1) Carper, BA. : Fundamental patterns of khowing in nursing, Ad-vances in Nursing Scence, 1, 13-23, 1978.

2 ) 外口玉子：人と場をつなぐケア こころ病
みつつ生きることへ, 医学書院, 1988.

3 ) 高田早苗 : 看護診断を用いない理由一看護 学と実践の目指す方向からの批判一, 月刊 ナースデー夕, 18 (2), 5-11, 1997.

4) Wiedenbach, E., 外口玉子他訳 : 臨床看 護の本質, 現代社, 1969.

5 ) Benner, P., 井部俊子他訳 : ベナー看護論 達人ナースの卓越性とパワー, 医学書院, 1992.

6 ) Stevens, JB., 中西睦子訳 : 看護理論の理 解のために その分析／適用／評価, メデ ィカル・サイエンス・インターナショナル, 1982.

7 ) Reverby, S. : A caring dilemma: Womanhood and nursing in historical perspective, Nursing Research, 36 (1), 5-11, 1986. 